\title{
Diyabetik Ayak Yarası Olan Hastaların Yașam Kalitesi
}

\section{The Quality of Life in the Patients with Diabetic Foot Ulcers}

\author{
Özlem KUMAN TUNÇEL'(iD), Merve MERT²(IID), Hüseyin Aytaç ERDEM²(IiD), Anıl Murat ÖZTÜRK3(IiD),

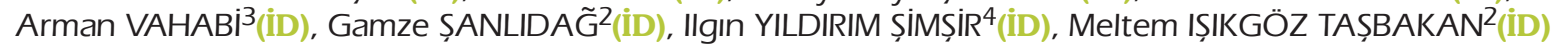

\author{
1 Ege Üniversitesi Tıp Fakültesi, Ruh Sag̃lıg̃ı ve Hastalıkları Anabilim Dalı, İzmir, Türkiye \\ 2 Ege Üniversitesi Tıp Fakültesi, İnfeksiyon Hastalıkları ve Klinik Mikrobiyoloji Anabilim Dalı, İzmir, Türkiye \\ ${ }^{3}$ Ege Üniversitesi Tıp Fakültesi, Ortopedi ve Travmatoloji Anabilim Dalı, İzmir, Türkiye \\ ${ }^{4}$ Ege Üniversitesi Tıp Fakültesi, iç Hastalıkıarı Anabilim Dalı, Endokrinoloji ve Metabolizma Hastalıkıarı Bilim Dalı, İzmir, Türkiye
}

Makale atıfı: Kuman Tunçel Ö, Mert M, Erdem HA, Öztürk MA, Vahabi A, Şanlıdağ G ve ark. Diyabetik ayak yarası olan hastaların yașam kalitesi. FLORA 2021;26(2):295-302.

\section{ÖZ}

Giriş: Diabetes Mellitus (DM) komplikasyonlarından biri olan diyabetik ayak yarası (DAY) diyabetik hastaların en sık hastaneye yatış nedenidir; ekstremite ampütasyonlarına ve mortalitede artısa neden olmaktadır. DAY, hastalara fiziksel ve emosyonel olarak ek bir yük getirmekte, yaşam kalitelerini olumsuz yönde etkilemektedir. Türkiye'de DAY hastalarının yaşam kalitesi ve psikolojik durumunu araştıran çalışma sayısının kısıtı olması nedeniyle DAY hastalarının anksiyete, depresyon ve yaşam kalitesi düzeylerinin diyabetik, DAY olmayan hastalar ile karşılaştııılması amacıyla bu çalışma planlanmıştır.

Materyal ve Metod: Kesitsel desendeki bu çalışmaya Ege Üniversitesi Tıp Fakültesi Infeksiyon Hastalıkları ve Klinik Mikrobiyoloji Kliniği tarafından izlenmekte olan DM tanılı ve katılmaya gönüllü 133 hasta katılmışır. Hastaların sosyodemografik bilgilerinin yanı sıra Hastane Anksiyete Depresyon (HAD) Ölçeğiyle anksiyete ve depresyon düzeyleri; Kısa Form-36 (SF-36) ile yaşam kaliteleri değerlendirilmiştir.

Bulgular: Yaş ortancası 60 yıl olan 133 DM hastasının 83'ü DAY grubundaydı. DAY grubunda yaş ortalaması daha yüksek ( $p=0.006$; $t=-2.813)$ ve erkek yoğunluğu daha fazlaydı $\left(p=0.0002 ; \chi^{2}=13.824\right)$. iki grup arasında SF-36 ve HAD puanları içinde sadece fiziksel fonksiyon puanının DAY grubunda daha düşük $(p=0.002 ; Z=-3.04)$ olduğu saptanmıştır. DAY grubu ile diğer diyabetli hastaların SF-36 alt ölçek sonuçları Türkiye norm değerleri ile karşılaştııılığında iki grupta da katılımcıların tüm alt ölçekler açısından Türkiye normlarından düşük puanlarının olduğu saptanmıştır $(p<0.0001)$.

Sonuç: DAY olan hastaların diğer DM hastalarından fiziksel fonksiyonlar açısından yaşam kalitelerinin daha kötü olduğunun saptanması, DAY hastalarının tedavisinde ayak yarasına yönelik medikal ve cerrahi tedaviler yanında fiziksel fonksiyonlarını ve buna bağlı olarak yaşam kalitelerini geliştirecek girişimlerde de bulunulması gerektiğini göstermektedir. Çalışmamızda Türkiye norm değerleri ile karşılaştırıldığında tüm diyabetik hastaların, genel popülasyona kıyasla her alanda yaşam kalitelerinin daha düşük olduğu bulunmuştur. Bu durum DM hastalarının ve özellikle DAY'ı olan hastaların yaşam kalitelerinin iyileştirilmesi için bazı adımlar atılması gerektiğini vurgulamaktadır.

Anahtar Kelimeler: Anksiyete; Depresyon; Diabetes Mellitus; Diyabetik ayak yarası; Yaşam kalitesi

Geliș Tarihi/Received: 28/03/2021 - Kabul Ediliș Tarihi/Accepted: 12/04/2021

${ }^{\circ}$ Telif Haklı 2021 Flora. Makale metnine www.floradergisi.org web adresinden ulașılabilir. 


\title{
ABSTRACT \\ The Quality of Life in the Patients with Diabetic Foot Ulcers
}

\author{
Özlem KUMAN TUNÇEL' ${ }^{1}$, Merve MERT'2, Hüseyin Aytaç ERDEM², Anıl Murat ÖZTÜRK ${ }^{3}$, Arman VAHABi' ${ }^{3}$, \\ Gamze ȘANLIDA $\tilde{G}^{2}$, Ilgın YILDIRIM ȘiMȘiR ${ }^{4}$, Meltem IȘIKGÖZ TAȘBAKAN²
}

\footnotetext{
1 Department of Mental Health and Diseases, Ege University Faculty of Medicine, İzmir, Turkey

${ }^{2}$ Department of Infectious Diseases and Clinical Microbiology, Ege University Faculty of Medicine, İzmir, Turkey

3 Department of Orthopedics and Traumatology, Ege University Faculty of Medicine, İmir, Turkey

${ }^{4}$ Department of Internal Diseases, Division of Endocrinology and Metabolic Diseases, Ege University Faculty of Medicine, İzmir, Turkey
}

\begin{abstract}
Introduction: Diabetic foot ulcer (DFU), one of the complications of Diabetes Mellitus (DM), is the most common reason for the hospitalization of diabetic patients and leads to extremity amputations and increase in mortality. DFU brings an additional physical and emotional burden to the patients and affects their quality of life (QoL) negatively. This study was organized with the aim of comparing the anxiety, depression and QoL levels of DFU patients with diabetic patients without DFU due to the limited number of the studies investigating the QoL and mental health of DFU patients.
\end{abstract}

Materials and Methods: One hundred and thirty-three patients followed up in the X University Faculty of Medicine Infectious Diseases and Clinical Microbiology Department and volunteered to participate in this cross-sectional study. Besides sociodemographic information, anxiety and depression levels were assessed by Hospital Anxiety Depression (HAD) Scale and QoL was measured by Short Form 36 (SF-36).

Results: Among the 133 DM patients with a median age of 60 years, 83 patients were in the DFU group. Mean age $(p=0.006, t=$ $-2.813)$ and male prevalence $\left(p=0.0002, \chi^{2}=13.824\right)$ were higher in the DFU group. Only physical functioning scores were lower in the DFU group ( $p=0.002, Z=-3.04$ ) while comparing SF-36 and HAD scores between the two groups. All SF-36 subscale scores of both diabetic groups were lower than the Turkish normative values $(p<0.0001)$.

Conclusion: Finding worse QoL in the aspect of physical functioning among DFU patients reveals the necessity of interventions that will improve the DFU patients' QoL by increasing their physical functioning, besides medical and surgical treatments for foot ulcers. In our study, it was found that all diabetic patients had lower QoL than the normal population. This finding emphasizes the need for taking steps to improve the QoL of patients with DM and especially DFU.

Key Words: Anxiety; Depression; Diabetic foot ulcer; Diabetes mellitus; Quality of life

\section{GiRiș}

Diabetes Mellitus (DM), insülin eksikliği ya da insülin etkisindeki defektler nedeniyle karbonhidrat, yağ ve proteinlerden yeterince yararlanamama seklinde kendini gösteren, süreğen bir metabolizma bozukluğudur. DM'nin komplikasyonlarından biri olan diyabetik ayak yarası (DAY) DM hastalarının en sık hastaneye yatıs ve en uzun süre hastanede kalma nedenidir. Bir DM hastasının yașamı boyunca \%12-25 oranında DAY gelistirme riski vardır. DAY alt ekstremite ampütasyonlarına ve mortalitede artıșa neden olmaktadır ${ }^{[1]}$. Ülkemizden bildirilen bir çalıșmada DAY'da reampütasyon oranı \%17.9 olarak saptanmıstır ${ }^{[2]}$

Kronik bir süreci olan DM; psikolojik, sosyal ve psikoseksüel birçok catıșma ve soruna neden olabilmektedir. Kan sekerindeki oynamalar psikolojik durumu etkileyebilmektedir. Diyabette en skk, depresyon ve anksiyete bozuklukları görülmektedir ${ }^{[3]}$. Depresyon varlı̆̆ DM hastalarında DAY gelișme riskini arttırmaktadır ${ }^{[4]}$. DAY, DM hastalarına fiziksel ve emosyonel olarak ek bir yük getirmektedir. Bir çalısmada ilk kez DAY gelișen DM hastalarının yaklașık 1/3'ünün depresif olduğu ve DAY hastalarında depresyon varlığının mortaliteyi arttırdığı saptanmıștır ${ }^{[5]}$. Yakın tarihli sistematik bir gözden geçirme çalıșmasında, önceden DAY olmayan DM hastalarında Hastane Anksiyete Depresyon (HAD) ölçeğinde depresyon puanındaki bir puan artısıın DAY olușma riskini yaklașık iki kat arttırdığı saptanmıștır. Aynı yayında, düşük kanıt düzeyi olmakla birlikte DAY'1 olanlarda depresyon varlığının rekürrens ile iliskili 
olmayabileceği gösterilmiș, DAY ile anksiyete arasındaki ilișkiyi araștıran çalıșmaların yetersiz olduğu bildirilmiștir ${ }^{[4]}$. Bir bașka calıșmada ise DAY hastalarında depresyon varlığının ampütasyon riskini \%33 arttırdı̆̆ı saptanmıștır[6].

Diyabetik ayak yarası varlığı hastaların yașam kalitesini de olumsuz yönde etkilemektedir ${ }^{[7]}$. Daha siddetli ağrı tanımlayan hastaların yașam kalitelerinin daha kötü olduğu saptanmıștır ${ }^{[8]}$. Bir çalıșmada cinsiyetin yașam kalitesi açısından ön gördürücü olmadığı gösterilmișken ${ }^{[9]}$, bașka bir calıșmada kadın DAY hastalarının yașam kalitelerinin erkek DAY hastalarından daha düșuik olduğu gösterilmistir ${ }^{[10]}$. Nemcova ve arkadașları bir partnerle beraber yașayanların psikolojik ve cevresel alanda daha iyi yașam kalitesine sahip olduklarını göstermișken ${ }^{[11]}$, diğer bir çalıșmada evlilik durumunun yașam kalitesi açısından ön gördürücü olmadığı gösterilmiștir ${ }^{[9]}$. Yüksek hemoglobin A1c (HbA1c) düzeyinin vitalite ve genel sağlık algısı üzerine olumsuz etki gösterdiği saptanmıștır ${ }^{[12]}$. Bunların yanı sıra farklı çalıșmalarda vücut kütle indeksinin $^{[11-13]}$, DAY süresinin ${ }^{[9-11]}$, DAY siddetinin ${ }^{[14]}$, yaranın $5 \mathrm{~cm}^{2}$ 'den büyük olmasının ${ }^{[13]}$ ve DAY'a bağlı ağrı varlığının ${ }^{[8,11]}$ yașam kalitesini olumsuz yönde etkilediğini gösteren kanttlar da bildirilmiștir.

Türkiye'de DAY'ın hastaların yașam kalitesi ve psikolojik durumu üzerine etkisini araștıran calıșma sayısı kısıtlıdır. Toygar ve arkadașlarının calıșmasında tedavi türünün ve diyabete eșlik eden kronik hastalık varlığının yașam kalitesi toplam puanını etkilediği gösterilmiștir ${ }^{[15]}$. Yayınlanmamıs bir tez calıșmasında DAY hastalarının yașam kalitesi düzeylerinin orta düzeyin üzerinde olduğu ve sosyal desteğin yașam kalitesi üzerine önemli bir etkisinin olduğu saptanmıștır ${ }^{[16]}$. Yıldız ve arkadașlarının çalıșmasında da sosyal destek düzeyinin depresyon düzeyi ile negatif korelasyon gösterdiği saptanmıștır. Bu çalıșmada DM süresi, hospitalizasyon sıklığı ile depresyon düzeyi arasında bir ilișki saptanmamıștır [17].

Calıșmamız, Türkiye'de DAY hastalarının yasam kalitesi ve psikiyatrik durumu ile ilgili çalıșma sayısının kısıtlılığı göz önünde bulundurularak DAY olan hastaların anksiyete, depresyon ve yașam kalitesi düzeylerinin DM tanil ama DAY olmayan hastalar ile karșılaștırılması amacıyla planlanmıștır.

\section{MATERYAL ve METOD}

Çalıșmanın örneklem grubunu Ege Úniversitesi Tıp Fakültesi İnfeksiyon Hastalıkları ve Klinik Mikrobiyoloji Kliniği tarafından izlenmekte olan DM tanılı ve calıșmaya katılmaya gönüllü 133 hasta olușturmuștur. Çalıșmanın içleme ölçütleri 18 yasından büyük olmak, DM tanılı olmak, çalıșmaya katılmaya gönüllü olmak ve bilgilendirilmiș onam verebilecek bilisssel kapasitede olmak seklinde belirlenmiștir. Bilinen psikotik bozukluk, sizofreni, demans, bipolar bozukluk ve mental retardasyon tanıs1; yașam kalitesini ve ișlevselliği belirgin derecede bozan ek kronik hastalık varlığı; gebelik; 18 yașından kücük ve gönüllü olmamak ise dișlama ölçütlerini olușturmuștur. Bu ölçütlere uygun olan hastalar calıșma hakkında bilgilendirildikten sonra gönüllü olanlardan yazılı onam alınmıștır. Calıșma için Ege Üniversitesi Tip Fakültesi Tıbbi Araștırmalar Etik Kurulundan onay alınmıștır.

Calıșma kapsamında, hastalarla yapılan görüșme ve tıbbi kayitlarının incelenmesi sonucunda hastaların sosyodemografik bilgileri ve DM ile ilgili klinik özellikleri elde edilmiștir. Hastaların anksiyete ve depresyon düzeyini belirlemek için HAD; yașam kalitesini değerlendirmek için Kısa Form-36 (SF-36) kullanılmıstır. HAD, Zigmond ve Snaith tarafından gelistirilmiș bir ölçektir ${ }^{[18]}$. Türkçe uyarlaması ve geçerlik güvenirlik çalıșması Aydemir ve arkadașları tarafından 1997 yılında yapılmıștır ${ }^{[19]}$. Uygulaması kolay bir öz bildirim ölçeğidir. Bedensel hastalığı olanlara uygulanabilir. Toplam 14 soru içermektedir; bunların yedisi anksiyeteyi, diğer yedisi ise depresyonu ölçmektedir. Dörtlü Likert tipi ölçüm sağlamaktadır. Türkiye'de yapilan çalıșma sonucunda anksiyete alt ölçeği için kesme puanı 10/11; depresyon alt ölçeği için ise 7/8 olarak bulunmuștur. SF-36 fiziksel fonksiyon, rol kisıtlamaları (fiziksel ve emosyonel sorunlara bağli), sosyal fonksiyon, mental sağlık, vitalite, ağrı ve sağlığın genel olarak algılanması gibi sağlığın 8 boyutunu 36 madde ile incelemektedir. Ware ve Sherbourne $e^{[20]}$ tarafından geliștirilen ölçeğin Türkçe geçerlik ve güvenirlik calıșması Koçyiğit ve arkadașları tarafından 1999 yılında yapılmıstır $^{[21]}$. Demiral ve arkadașları (2004), SF36 için Türk toplum standartlarının belirlenmesi calıșmasını yapmıșlardır ${ }^{[22]}$. 
İstatistiksel analiz için SPSS V21 paket programı kullanılmıștır. Normal dağılımın kontrolü için Shapiro Wilk testi kullanılmıștır. Nicel değiskenlerden normal dağllım gösterenler ortalama ve standart sapma ile, normal dağılım göstermeyenler ise medyan, maksimum ve minimum değerler ya da ceyrekler arası aralık ile özetlenmiștir. Nicel değișkenleri karșılaștırırken gruplar arasında fark olup olmadığını belirlemek için normal dağılım gösterenler için student $\mathrm{T}$ testi; normal dağılım göstermeyenler için Mann Whitney U testi kullanılmıștır. İki grup arasında kategorik değișkenleri karșılaștırırken ki-kare testi kullanılmıștır. Nicel değiskenlerin birbirleri arasındaki korelasyonu belirlemek için normal dağıllım gösterenler için Pearson; normal dağılım göstermeyenler için Spearmann korelasyon analizi kullanılmıștır. $\mathrm{p}<0.05$ olması istatistiksel anlamlı kabul edilmiștir.

\section{BULGULAR}

Calıșmaya yaș aralığı 19-96, yaș ortancası 60 yıl olan 133 gönüllü DM hastası katılmıștır. Katılımclardan 83 (\%62.4)'ü DAY grubundayken 50 (\%37.6)'sinin DAY'1 yoktu. DAY grubunun sosyodemografik ve psikometrik sonuçlarının diğer diyabetli hastalarla karșılaștırılması Tablo 1'de verilmiștir. DAY olmayan grupta yas ile psikometrik değerlendirmelerden sadece fiziksel fonksiyon puanları arasında istatistiksel anlaml bir korelasyon saptanmıștır ( $p=0.006 ; r=-0.387)$. DAY grubunda ise böyle bir ilișki bulunmamıștır. Cinsiyetin psikometrik ölçümlerle ilișkisi araștırıldığında DAY grubunda kadınların anksiyete $(\mathrm{p}=0.025$; $Z=-0.912$ ) puanlarının daha yüksek; fiziksel rol güçlüğu ( $p=0.042 ; Z=-2.037)$ puanlarının ise daha düsüuk olduğu saptanmıstır. DAY olmayan grupta ise cinsiyetle sadece anksiyete $(\mathrm{p}=0.011$, $Z=-2.546)$ puanları arasında ilișki saptanmıștır. Kadınların (ortancalar: 8 ve 6) anksiyete puanlarının daha yüksek olduğu bulunmuștur.

Bir katılımc1 SF-36 formunu doldurmamıstır. DAY grubu ile diğer diyabetli hastaların SF-36 alt ölçek sonuçları Türkiye norm değerleri ${ }^{[22]}$ ile karșllaștıııldığında hem DAY grubunda hem de DAY olmayan grupta katılımcların tüm alt ölcekler açısından Türkiye normlarından düșük puanlarının olduğu saptanmıștır $(p<0.0001)$. Bu karșlaștırmalar hata cubukları ile Grafik 1 ve 2'de sunulmustur.

\begin{tabular}{|c|c|c|c|}
\hline Değişkenler & $\mathrm{DAY}+(\mathrm{n}=83)$ & DAY- $(n=50)$ & İstatistik \\
\hline Yaş, ortalama \pm SS & $61.7 \pm 10.4$ & $54.9 \pm 14.8$ & $p=0.006 ; t=-2.813$ \\
\hline Kadın, n (\%) & $23(\% 27.7)$ & $31(\% 62)$ & $p=0.0002 ; \chi^{2}=13.824$ \\
\hline Genel sağlık, ortanca (ÇAA)* & $40(42)$ & $45(32.5)$ & $p=0.941 ; Z=-0.074$ \\
\hline Fiziksel fonksiyon, ortanca (ÇAA)† & $25(50)$ & $45(57.5)$ & $p=0.002 ; Z=-3.04$ \\
\hline Fiziksel rol güçlüğü, ortanca (ÇAA)ý & $0(25)$ & $0(68.5)$ & $p=0.331 ; Z=-0.971$ \\
\hline Ağrı, ortanca $(C ̧ A A)^{y ́}$ & $41(40)$ & $51(39)$ & $p=0.184 ; Z=-1.328$ \\
\hline Vitalite, ortalama \pm SS $†$ & $46.28 \pm 24.09$ & $46.2 \pm 21.27$ & $p=0.984 ; t=0.02$ \\
\hline Sosyal fonksiyon, ortanca (ÇAA) $)^{\S}$ & $50(46.88)$ & $50(50)$ & $p=0.328 ; Z=-0.979$ \\
\hline Emosyonel rol güçlüğü, ortanca (ÇAA)" & $33.33(66.67)$ & $33.33(66.67)$ & $p=0.772 ; Z=-0.290$ \\
\hline Mental sağlık, ortalama $\pm S S^{\S}$ & $58.05 \pm 19.61$ & $56.08 \pm 16.78$ & $p=0.711 ; t=0.371$ \\
\hline HAD-A, ortanca $(C ̧ A A)^{q 1}$ & $6.5(6)$ & $7(7)$ & $p=0.296 ; Z=-1.045$ \\
\hline HAD-D, ortalama \pm SS & $8.16 \pm 4.08$ & $7.7 \pm 4.47$ & $p=0.547 ; t=0.604$ \\
\hline Anksiyete bozukluğu riski, n (\%) & $17(\% 20.5)$ & $15(\% 30)$ & $p=0.301 ; \chi^{2}=1.07$ \\
\hline Depresyon riski, n (\%) & $42(\% 51.2)$ & $24(\% 48)$ & $p=0.720 ; \chi^{2}=0.129$ \\
\hline
\end{tabular}

DAY+: Diyabetik ayak yarası olan grup, DAY-: Diyabetik ayak yarası olmayan grup, SS: Standart sapma, ÇAA: Çeyrekler arası aralık.

*: Veriler 130 kişi için mevcuttur. †: Veriler 128 kişi için mevcuttur. ý: Veriler 127 kişi için mevcuttur. §̊: Veriler 126 kişi için mevcuttur.

\|: Veriler 124 kişi için mevcuttur. q: Veriler 132 kişi için mevcuttur. 


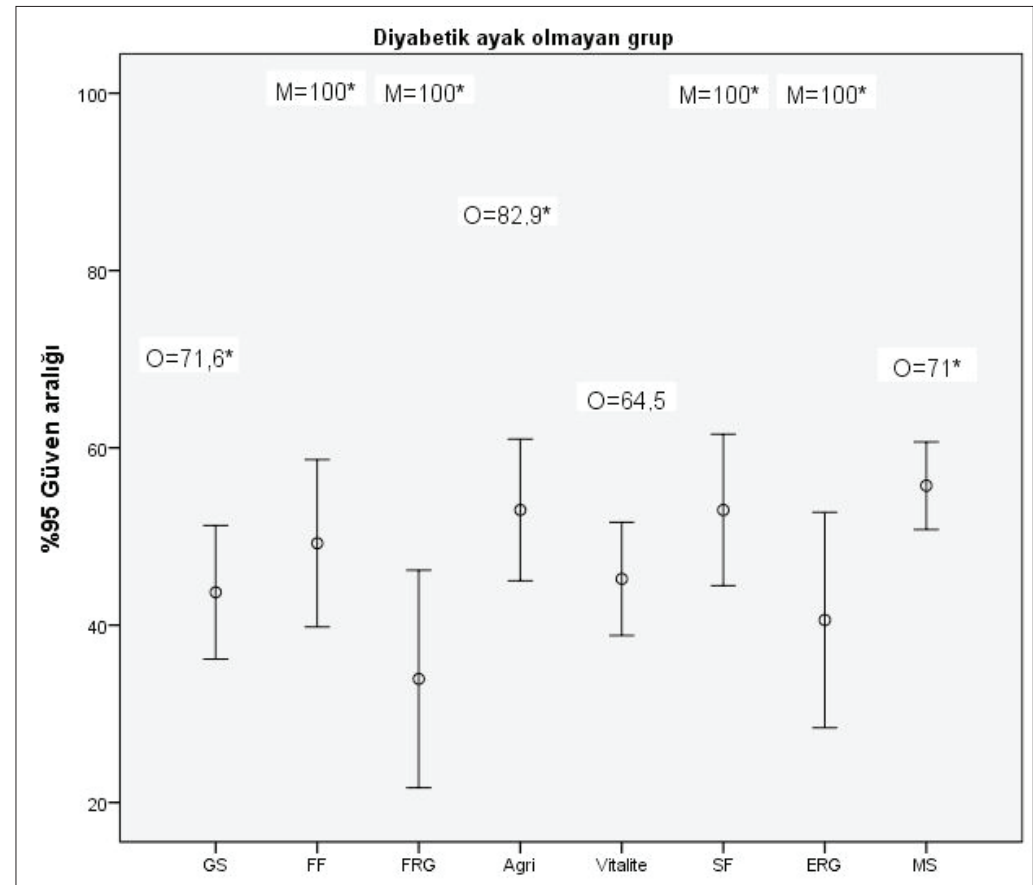

Şekil 1. Diyabetik ayak yarası grubunun Kısa Form-36 sonuçlarının Türkiye norm değerleri ile karşılaştırılması.

Kutucuklar içindeki değerler Türkiye normlarını göstermektedir

M: Medyan, O: Ortalama, GS: Genel sağlık, FF: Fiziksel fonksiyon, FRG: Fiziksel rol güçlüğü, SF: Sosyal fonksiyon, ERG: Emosyonel rol güçlüğü, MS: Mental sağlık. ${ }^{*}: p<0.0001$.

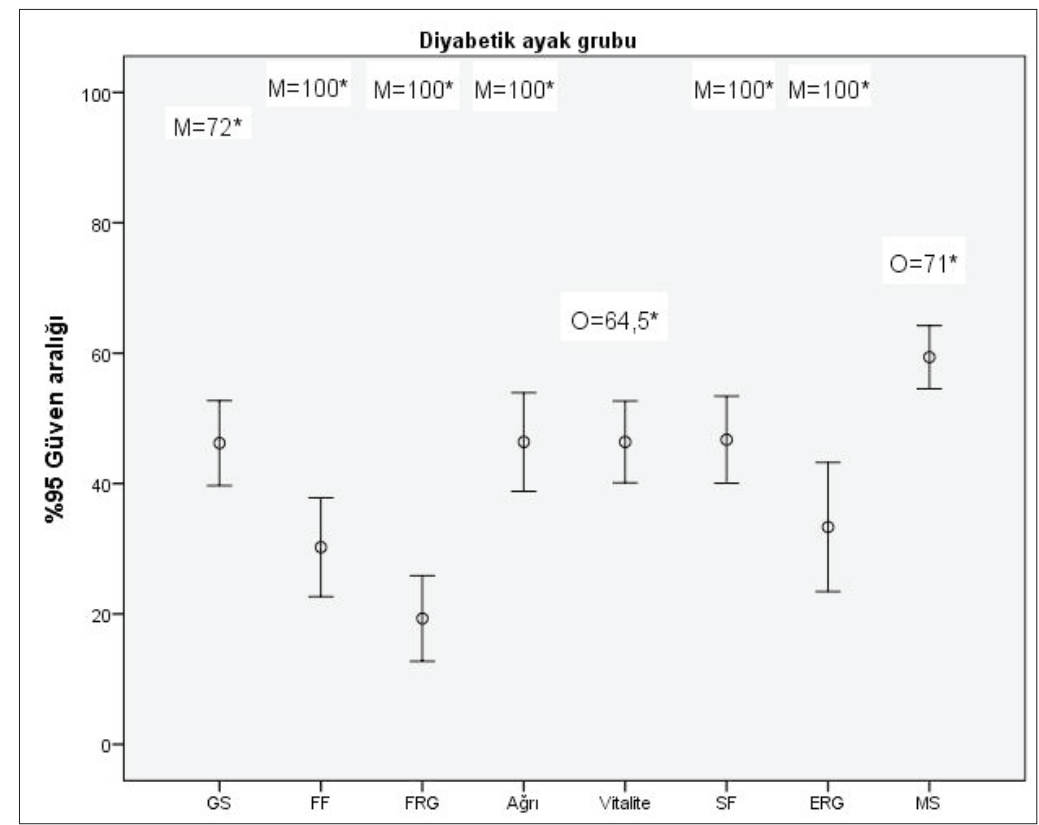

Şekil 2. Diyabetik ayak yarası olmayan grubunun Kısa Form-36 sonuçlarının Türkiye norm değerleri ile karşılaştırılması.

M: Medyan, O: Ortalama, GS: Genel sağlık, FF: Fiziksel fonksiyon, FRG: Fiziksel rol güçlüğü, SF: Sosyal fonksiyon, ERG: Emosyonel rol güçlüğü, MS: Mental sağlık. 


\section{TARTIȘMA}

Calıșmamızda DAY olan hastaların diğer DM hastalarından fiziksel fonksiyonlar açısından yașam kalitelerinin daha kötü olduğu saptanmıștır. Türkiye norm değerleri ile karșlaștırıldığında DAY hastalarının, genel popülasyona kıyasla her alanda yașam kalitelerinin daha düșük olduğu bulunmuştur. Bu durum DAY olan hastaların yașam kalitelerinin iyileștirilmesi için bazı adımlar atılması gerektiğini göstermektedir.

DAY olan grubun diğer gruptan daha yașl1 olması ve erkek oranının istatistiksel anlamlı olarak daha yüksek bulunması DAY'in artan yas ve erkek cinsiyetle ilișkili olması açısından literatürle uyumludur ${ }^{[23,24]}$

Sanjari ve arkadașlarının SF-36 ile 54 DAY hastasını 78 DAY olmayan DM hastası ile karș1laștırdıkları calıșmada bizim sonuçlarımıza benzer sekilde fiziksel fonksiyon puanlarının DAY grubunda daha düsüük olduğu saptanmıștır ${ }^{[7]}$. SF-36'nın bu alt ölçeğinde yer alan sorular incelendiğinde cesitli mesafelerde yürüme, merdiven çkma, günlük alıșeriș eșyalarını tașıma, kendi kendine banyo yapma ya da giyinme gibi temel günlük ișlevlerin DAY olan hastalarda bozulduğu anlasılmaktadır. Bu da DAY tedavisinin hastaların günlük hayatı üzerindeki önemini göstermektedir.

Calıșmamızda SF-36 ölçeğinin kullanılması sayesinde katılımcıların yașam kalitesi puanları Türkiye norm değerleri ile de karșlaștırılabilmiștir. Türkiye normları ile ilgili çalıșmanın da șehrimizde yapılmıs olması, coğrafik etkilenmelerin ortadan kalkmasını sağlamaktadır. DAY hastalarının tüm alt ölçekler açısından Türkiye normlarından daha düșük yașam kalitesine sahip olmaları bu hasta grubunun genel etkilenme düzeylerini göstermesi açısından önemlidir. Bir yıllık bir izlem calıșmasında DAY hastalarında düșük yașam kalitesinin ampütasyon ve ölüm için ön gördürücü olduğunun saptandığı ${ }^{[25]}$ göz önünde bulundurulduğunda, DAY hastalarının özellikle fiziksel fonksiyonlar1na yönelik yașam kalitelerini arttırıcı girișimlerde bulunulması gerektiŏi açıktır. Calıșmamızda DAY olmayan DM hastalarının da yașam kalitelerinin her alt ölçekte toplum normlarından daha düșük olduğu saptanmıștır. Calıșmamızın üçüncü basamak bir üniversite hastanesinde yapılmıs olması ve buna bağlı olarak da bu merkezde izlenen daha komplike DM hastalarının calıșmaya katılmıs olması bu sonuça ilișkili olabilir. Ayrıca Türk hastaların sonuçlarının farklı ülkelerdeki DM hastalarının sonuçları ile karșllaștırıldığı bir bașka calıșmada Türk DM hastalarının depresif yakınmalarının daha fazla, DM ile ilgili özbakım davranıșlarının ise daha az olduğu saptanmıstır [26]. Bu durum DM hastalarının genelinde yașam kalitesinde düsüklük saptanmasına neden olabilir.

Sistematik bir gözden geçirme calıșmasında bes calıșmanın SF-36 sonuçları değerlendirmeye alındığında, alt ölçek puan ortalamaları ağrı için 45.75; sosyal fonksiyon için 54.09; emosyonel rol güçlüğü için 46.67; mental sağlık için 55.26; vitalite için 45.73; fiziksel rol güçlüğü için 20.61; genel sağlık algısı için 35.5 ve fiziksel fonksiyon için 45.58 olarak saptanmıștır ${ }^{[27]}$. Sonuçlarımız bu ortalamalar ile karșılaștırıldığında, fiziksel fonksiyon puanları disında genel olarak sonuçarın benzer olduğu görülmektedir. Türkiye'deki DAY hastalarının fiziksel fonksiyonlarının daha kötü olması gelecekteki calıșmalarda incelenmesi gereken bir durumdur.

Goodridge ve arkadașlarının sonuçlarına benzer sekilde calısmamıza katılan DAY hastalarında yas ile yasam kalitesi arasında bir iliski saptanmamıștır ${ }^{[9]}$. Sonuçlarımızdan farklı olarak 67 yaș üzerindeki hastaların emosyonel rol güclüğü puanının, 40-66 yas arasındakilere kıyasla daha düșük olduğunu gösteren ${ }^{[13]}$ ya da yas ile psikolojik ve sosyal yasam kalitesi arasında olumsuz bir ilișki saptayan ${ }^{[11]}$ calıșmalar da mevcuttur. Ribu ve arkadașlarının çalıșmasında kadın hastaların vitalite ve mental sağlık puanlarının daha düșük olduğu saptanmıșken ${ }^{[13]}$ bizim calıșmamızda sadece fiziksel rol güclüğü puanlarının daha düsük olduğu saptanmıștır. Toygar ve arkadașlarının çalıșmasında kullanılan yașam kalitesi ölçeğinin lezyon, fiziksel sağlık, bağımlılık/günlük yașam aktiviteleri, ülser bakımından rahatsız olma ve ölçek toplam puanında kadınların daha iyi sonuçar elde ettiği saptanmıștır ${ }^{[15]}$. Hem DAY grubunda hem de diğer grupta kadınların anksiyete puanlarının daha yüksek olarak saptanması genel popülasyonda anksiyete bozukluklarının kadınlarda daha sık saptanmasi $^{[28]}$ ile ilișkili gibi görünmektedir. 
Calıșmamızın tek merkezde yapilmıs olması, kısıtlı örneklem büyüklüğü ve yașam kalitesi ile anksiyete ve depresyon düzeylerinin öz bildirim ölçekleri ile değerlendirilmiș olması calıșmanın k1sitllikları arasında yer almaktadır. Diyabetik ayak ya da diyabet için geliștirilmiș bir yașam kalitesi ölçeğinin kullanılmamıs olması da bir kısıtlllık sayllabilir. Ancak, SF-36 gibi bir jenerik ölçeğin uygulanılmıs olması katılımciların yașam kalitelerinin toplum normları ile karșlaștırılmasını sağlayarak çalıșmamızın sonuçlarını zenginleștirmiștir.

Sonuc olarak, çalıșmamizda DAY hastalarının fiziksel fonksiyon açısından yaşam kalitelerinin olumsuz etkilendiği gösterilmiștir. DAY hastalarının tedavisinde ayak yarasına yönelik medikal ve cerrahi tedaviler yanında fiziksel fonksiyonlarını ve buna bağlı olarak yașam kalitelerini geliștirecek girisimlerde de bulunulması gerekmekte ve önem olușturmaktadir.

\section{ETIK KURUL ONAYI}

Calıșma için Ege Üniversitesi Tıp Fakültesi Tıbbi Araștırmalar Etik Kurulundan onay alındı (Tarih: 22.07.2020, Karar No: E.180147).

\section{ÇIKAR ÇATIȘMASI}

Yazarlar bu makale ile ilgili herhangi bir çkar catıșması bildirmemișlerdir.

\section{YAZAR KATKISI}

Anafikir/Planlama: Tüm yazarlar

Analiz/Yorum: ÖKT, IYS,, MIT

Veri sağlama: MM, HAE, AMÖ, AV, GS,

IYS, MIT

Yazım: ÖKT

Gözden Geçirme ve Düzeltme: Tüm yazarlar

Onaylama: Tüm yazarlar

\section{KAYNAKLAR}

1. TEMD Diabetes Mellitus Çalışma ve Eğitim Grubu. TEMD Diabetes Mellitus ve Komplikasyonlarının Tanı ve Tedavi izlem Kılavuzu-2020. Ankara: Türkiye Endokrinoloji ve Metabolizma Derneği, 2020.

2. Yıldırım Şimşir I, Özturk MA, Shamistanli Y, Taşbakan Işıkgöz $M$, Çetinkalp Ş. Diyabetik Ayakta Alt Ekstremite Re-ampütasyonları Kaçınılmaz mı? FLORA 2018;23:202-7.

3. Toker-Uğurlu T, Çulha-Ateş̧̧i F. Metabolik ve Endokrin Bozukluklar. In: Elbi H, Cimilli C, Önen Sertöz Ö, Karşıdağ Ç, Sözeri Varma G (eds). Konsultasyon Liyezon Psikiyatrisi. Ankara: Bayt Bilimsel Araştırmalar Basın Yayın ve Tanıtım Ltd Şti; 2019.
4. Westby M, Norman G, Vedhara K, Game F, Cullum N. Psychosocial and behavioural prognostic factors for diabetic foot ulcer development and healing: a systematic review. Diabet Med 2020;37:1244-55.

5. Ismail K, Winkley K, Stahl D, Chalder T, Edmonds M. A cohort study of people with diabetes and their first foot ulcer: the role of depression on mortality. Diabetes Care 2007;30:1473-9.

6. Williams $L H$, Miller $D R$, Fincke $G$, Lafrance JP, Etzioni $R$, Maynard $C$, et al. Depression and incident lower limb amputations in veterans with diabetes. I Diabetes Complications 2011;25:175-82.

7. Sanjari M, Safari S, Shokoohi M, Safizade H, Rashidinezhad $H$, Mashrouteh $M$, et al. A cross-sectional study in Kerman, Iran, on the effect of diabetic foot ulcer on health-related quality of life. Int J Low Extrem Wounds 2011;10:200-6.

8. Ribu L, Rustoen T, Birkeland K, Hanestad BR, Paul SM, Miaskowski $C$. The prevalence and occurrence of diabetic foot ulcer pain and its impact on health-related quality of life. I Pain 2006;7:290-9.

9. Goodridge D, Trepman E, Sloan J, Guse L, Strain LA, McIntyre J, et al. Quality of life of adults with unhealed and healed diabetic foot ulcers. Foot Ankle Int 2006;27:274-80.

10. Garcia-Morales E, Lazaro-Martinez JL, Martinez-Hernandez $D$, Aragon-Sanchez J, Beneit-Montesinos JV, Gonzalez-Jurado MA. Impact of diabetic foot related complications on the Health Related Quality of Life (HRQol) of patients--a regional study in Spain. Int J Low Extrem Wounds 2011;10:6-11.

11. Nemcova J, Hlinkova E, Farsky I, Ziakova K, Jarosova D, Zelenikova $R$, et al. Quality of life in patients with diabetic foot ulcer in Visegrad countries. J Clin Nurs 2017;26:1245-56.

12. Yao H, Ting X, Minjie W, Yemin C, Xiqiao W, Yuzhi J, et al. The investigation of demographic characteristics and the health-related quality of life in patients with diabetic foot ulcers at first presentation. Int I Low Extrem Wounds 2012;11:187-93.

13. Ribu L, Hanestad BR, Moum T, Birkeland K, Rustoen T. Health-related quality of life among patients with diabetes and foot ulcers: association with demographic and clinical characteristics. J Diabetes Complications 2007;21:227-36.

14. Valensi P, Girod I, Baron F, Moreau-Defarges T, Guillon P. Quality of life and clinical correlates in patients with diabetic foot ulcers. Diabetes Metab 2005;31:263-71.

15. Toygar i, Hançerlioğlu S, Yıldırım Şimşir I, Çetinkalp Ş. Diyabetik ayak hastalarının yaşam kalitesi ve etkileyen faktörler. Ege Tip Dergisi 2020;59:272-9.

16. Canpolat M. Diyabetik Ayak Gelişen Hastalarda Algılanan Sosyal Destek ile Yaşam Kalitesi Arasındaki ilişkinin Belirlenmesi. Hemşirelik Anabilim Dalı, iç Hastalıkları Hemşireliği Yüksek Lisans Programı: Inönü Üniversitesi Sağlık Bilimleri Enstitüsü, 2018.

17. Yildiz E, Asti T. Determine the relationship between perceived social support and depression level of patients with diabetic foot. J Diabetes Metab Disord 2015;14:59. 
18. Zigmond AS, Snaith RP. The hospital anxiety and depression scale. Acta Psychiatr Scand 1983;67:361-70.

19. Aydemir Ö, Güvenir T, Küey L, Kültür S. Hastane Anksiyete Depresyon Ölçeği Türkçe formunun geçerlilik ve güvenilirliği Türk Psikiyatri Dergisi 1997:8:280-7.

20. Ware JE, Sherbourne CD. The MOS 36-item short-form health survey (SF-36). I. Conceptual framework and item selection. Med Care 1992;30:473-83.

21. Koçyiğit H, Aydemir Ö, Ölmez N, Memiş A. Kısa Form-36 (KF-36)'nın Türkçe versiyonunun güvenilirliği ve geçerliliği. ilaç ve Tedavi Dergisi 1999;12:102-6.

22. Demiral Y, Ergor G, Unal B, Semin S, Akvardar Y, Kivircik B, et al. Normative data and discriminative properties of short form 36 (SF-36) in Turkish urban population. BMC Public Health 2006;6:247.

23. Jalilian M, Ahmadi Sarbarzeh P, Oubari S. Factors related to severity of diabetic foot ulcer: a systematic review. Diabetes Metab Syndr Obes 2020;13:1835-42.

24. Seghieri G, De Bellis A, Seghieri M, Gualdani E, Policardo $L$, Franconi $F$, et al. Gender difference in the risk of adverse outcomes after diabetic foot disease: a mini-review. Curr Diabetes Rev 2021;17:207-13.

25. Siersma V, Thorsen $H$, Holstein PE, Kars M, Apelqvist J, Jude $E B$, et al. Health-related quality of life predicts major amputation and death, but not healing, in people with diabetes presenting with foot ulcers: the Eurodiale study. Diabetes Care 2014;37:694-700.
26. Tarkun I, Dumanli Ozgoksu S. Attitudes, wishes, and needs of diabetes patients and their relatives: Turkish data from the DAWN2 study. Turk I Med Sci 2017;47:447-54.

27. Khunkaew S, Fernandez $R$, Sim J. Health-related quality of life among adults living with diabetic foot ulcers: a meta-analysis. Qual Life Res 2019;28:1413-27.

28. Kessler RC, McGonagle KA, Zhao S, Nelson CB, Hughes M, Eshleman $S$, et al. Lifetime and 12-month prevalence of DSM-III-R psychiatric disorders in the united states. results from the national comorbidity survey. Arch Gen Psychiatry 1994;51:8-19.

\section{Yazıșma Adresi/Address for Correspondence} Prof. Dr. Meltem IȘIKGÖZ TAȘBAKAN

Ege Üniversitesi Tıp Fakültesi, İnfeksiyon Hastalıkları ve Klinik Mikrobiyoloji Anabilim Dalı, İzmir-Türkiye

E-posta: tasbakan@yahoo.com 